\title{
Effect of Employee Motivation on Job Performance: In Case of Fiche General Hospital
}

\author{
Dereje Muleta(MBA) \\ Department of Management, Salale University, PO box 245, Fiche, Ethiopia
}

\begin{abstract}
The research is financed by the researcher themselves
\end{abstract}
Abstract

This study had a major objective to investigate the effect of employee motivation on their job performance Fiche General hospital. It also intended to evaluate employee level of motivational and their level of job performance. In order to meet this objective the researcher has used simple random sampling techniques; in which data were collected from 179 participants out of 351, using likert scale questionnaires. Data has been analyzed in descriptive statistics to describe the level of the respective dependent and independent variable under considerations; and also correlation analysis and multiple regressions has been used to evaluate the effect of employee motivation on job performance in Fiche General Hospital. The data were analyzed using descriptive statistics (mean, and standard deviation) and inferential statistics (correlation and regression). The result of the descriptive statistics finding showed that the employee job performance has been under practiced in Fiche General Hospital. The results of inferential statistics have revealed that all motivational factors under study are positively related to employee job performance .According to this findings the employee empowerment practices is more significantly associated and impactful on employee job performance than all motivational factors under study. Therefore, the Fiche General Hospital has been suggested that more empowering their employee will better improve employee job performance. Hence, managers of Fiche General Hospital as advised to more empower their employee in the work place as motivational tool in order to enhance their job performance.

Keywords: Empowerment, Job performance, Motivation, Fiche General Hospital

DOI: $10.7176 / \mathrm{EJBM} / 12-7-06$

Publication date:March $31^{\text {st }} 2020$

\section{Introduction}

Motivation is one of the most important factors affecting human behavior. Motivation not only affects other cognitive factor like perception and learning but also affects total performance of an individual in organization setting. This is the reason why managers should attach great importance to motivation in organization. Motivation seems to be one of the most important tools for retaining employees and increases productivity. Organizations design motivation systems to encourage employees to perform in the most effective way and attract potential candidates. One of many ways to motivate employees is to give rewards and incentives for good performance (Daniel, A. 2012). Motivation that is characteristic of the job itself. According to Beer and Walton, 2014), intrinsic rewards accrue from performing the task itself, and may include the satisfaction of accomplishment or a sense of influence. Mosley, Pieria and Mosley Jnr. 2012) describe extrinsic motivation as the behavior performed, not for its own sake, but for the consequences associated with it. According to Stanley ,2012), in today's marketplace, where companies seek a competitive edge, motivation is key for talent retention and performance. The goal is to create a workplace that is engaging and motivating, where employees want to stay, grow and contribute their knowledge, experience and expertise. Chung ,2013) continues to state that in an effort to find the determinants of motivation and performance in industry, industrial psychologists and managerial practitioners have developed a variety of theories of (and approaches to) human motivation.

Many psychologists have developed motivational theories in terms of human needs or motives, while most management scholars have developed managerial theories in terms of incentives or inducements (Riggio, 2014) Traditionally, the study of job performance has been based on two somewhat independent assumptions: that performance can be understood in terms of the individual's ability to perform the tasks, and that performance depends solely upon the level of motivation (Chung, 2013). Motivation is generally defined as the psychological forces that determine the direction of a person's level of effort, as well as a person's persistence in the face of obstacles (Stanley, 2012). The responsibility for motivation is three-fold: it falls on the senior leadership, the direct manager and the employee. Numerous factors are involved, from trust, engagement and values (individual and organizational) to job satisfaction, achievement, acknowledgement and rewards. Motivation is essential for working autonomously, as well as for collaboration and effective teamwork (Stanley, 2012). Motivating employees for better performance encompasses these critical factors: employee engagement, organizational vision and values, management acknowledgment and appreciation of work well done, and overall authenticity of leadership. Performance appraisal is one of the most important human resource (HR) practice, administered in organizations by which supervisors evaluate the performance of subordinates implies that the focus of the performance appraisal is measuring and improving the actual performance of the employee and also the future 
potential of the employee; it aims to measure what an employee does.

Performance appraisal is generally regarded as one of the most crucial human resource management functions (Judge and Ferris 2013), furthermore; a competent performance appraisal and management system is an indispensable part of an organizations human resource management adequacies. Employee reactions to appraisal in terms of perceived employee fairness, accuracy, and satisfaction are important components of appraisal effectiveness because these perceived employee reactions can motivate employees to improve their performance. That is, performance appraisal serves as a means for providing feedback that can result in improved performance. Research in performance appraisal has demonstrated that performance appraisal characteristics (such as appraisal purpose and source) can elicit positive employee reactions to performance appraisal and, which in turn, can motivate employees to improve their performance.

Therefore, by focusing the attention on performance, performance appraisal goes to the heart of personnel management and sets out different objectives which are directly responsible for the Career development of employees and continued growth and development of the organizations. Employee turnover is a universal problem that all organizations around the world face (Stanley, 2012). One of the factors that contribute to high employee turnover is demonization. There is a growing consensus among managers and leaders about the significance of combining effective motivation incentives to encourage good performance (Cole and Kelly, 2011). In order for organizations to meet their objectives, they must have a workforce that is motivated and works towards achieving the objectives (Steers and Porter, 2011). Motivating employees is a challenge and keeping employees motivated an even greater challenge. Today, organizations are under intense pressure to identify and implement programs that will prove effective in improving employee productivity (Deci, 2013). It is no longer enough to increase salaries and expect increased performance; it is more complex than that Employee motivation affects productivity and a poorly motivated labor force will be costly to the organization in terms of lower productivity and performance, excessive staff turnover, increased expenses, frequent absenteeism and a negative effect on the morale of colleagues.

It is a well-known fact that the success of an organization largely depends on the quality of its human resource, irrespective of the Hospital within which it operates (Deci, 2013). It is with this in mind that leaders and managers must strive to ensure that their workforce is motivated and therefore productive. Motivation is seen as one of the most important factors in issues related to human resources management (HRM) and organizational behavior management (Nelson, 2013) Theories of job performance offer that motivation is a key determinant of performance The role of motivation in the work context has been studied to understand what causes employees to try hard to do well, or more specifically what causes the arousal, direction, and persistence of voluntary actions that are goal directed (Mitchell and Linden, 2012). It is therefore imperative that managers understand what motivates employees and also how to motivate them effectively (Deci, 2013).

\section{Statement of the Problem}

Motivation is the main core of employee job behavior field in the work environment (Masydzulhak, Ali, \& Anggraeni, 2016). Motivation is an important factor that helps employer to improve employee job performance (Sandhya \& Kumar, 2011). Motivation and performances of the employees are essential tools for the success of organization in the long run (Dobre, 2013). According to (Muogbo, 2013), the effect of motivation on employee job performance has been the focus of intensive research effort in recent times to identify how well an organization motivates its workers. There is positive relationship between employee motivation and employee job effectiveness (Dobre, 2013). The motivation of public service workers in developing and industrialized countries vary as workers earning low income are more extrinsically motivated and accept bribes in order to make ends meet (UNDP, 2014). Employee motivational factors will depend, not only on country level analysis, but also at regional, local and sector level (Devadass, 2011).

Low or complete lack of motivation in any organization has led to high turnover of employees, inefficiency, fraud, corruption, indiscipline at work (Muze, 2014). As per these scholar, (Matsie, 2008), (Temesgen, 2012), (Tizazu, 2015) and (Farooq \& Shafique, 2016), have put gap on these identified four basic variable of motivational factors on employee job performance. The study by (Muralidharan \& Sundararaman, 2009) shows payment is associated with output of employees and serves as incentive to enhance workers' performance. Developing and implementing employee training motivate workers (Dobre, 2013), increases productivity, improves the services and brings positive change in organization (Shaheen, Naqvi, \& Khan, 2013). The study by (Harrison \& Novak, 2006) reveals that efforts by management to establish promotion opportunities contributes to employee's job satisfaction and acts as a motivator for job performance. The study by (Manzoor, 2012) shows a positive relationship between employee empowerment and employee job effectiveness as the more the employees are motive to tasks accomplishment higher will the employee job performance.

Few studies have been done on motivational factors and job performance in service organization in Ethiopia. Some of them were conducted at federal owned and administered organization such as Factories (Ambo Mineral Water Factory etc.), Telecom, Banks (CBE) \& higher Educational institution etc. To the extent of my knowledge 
I have not seen studies at Fiche General Hospital regarding to effect of motivational factors on job performance. Thus, empirical and practical gaps support the importance of undertaking study on the effect of motivational factors on job performance at Fiche General Hospital

\section{Objectives of the study \\ General Objective}

This research intention is to examine the relationship between each motivational factor on performance FGH.

\section{Specific Objectives}

The Specific Objectives of the studs includes;

1. To identify the dominant motivational factors practiced in FGH.

2. To examine the relationship between each motivational factors and employee motivation in case of FGH.

3. To investigate the cumulative effect of motivational factors on employee performance in FGH.

4. To find which motivational factor is more important.

\section{Hypotheses of the Study}

\section{Hypotheses 1}

H1: There is a significant relationship between working condition and job performance.

$\mathrm{H} 0$ : There is no significant relationship between working condition and job performance

Hypotheses 2:

H1: There is a significant relationship between Benefits and job performance.

H0: There is no significant relationship between Benefits and job performance

Hypotheses 3:

H1: There is a significant relationship between Empowerment and job performance

H0: There is no significant relationship between Empowerment and job performance

Hypotheses 4:

H1: There is a significant relationship between Recognition and job performance

H0: There is no significant relationship between Recognition and job performance

\section{LITERATURE REVIEW}

\subsection{Types of Motivation}

2.1.1. Intrinsic Motivation: Intrinsic Motivation refers to individual motivation stimuli that are coming from within. A desire to perform a specific task because its results are in accordance with his belief system or fulfill a desire and therefore importance is attached to it. Our deep rooted desires have highest motivation power (Prasad, 2005).

There three forms of intrinsic motivation: In the first form people engage in activity for its own sake since they find the activity itself as a source of joy and satisfaction. Example: can be hobbies that one chooses to pursue in the work context fulfilling an interesting task. The second form is activities which are tedious and unexciting but their accomplishment is a source of pressure. For instance meeting a deadline at work brings a sense of achievement. Third form is about compliance it state that it is a matter of compliance with standard for their own sake that propels people to act. These standards may be ethical standards, commitment to group members, and desire to act according values of material or fairness procedure (Frey and Osterloh, 2002).

2.1.2. Extrinsic Motivation: According to Ryan \& Deci, 2000 extrinsic motivation is when people act because of external factors that prompt them to take action. Extrinsic motivation is concerned with whatever activity that is done to attain an outcome that is separable from the activity itself. In a career context extrinsic motivation means the desire to satisfy the need or goals that are not related to the work itself. For example, considering work as a mere tool for earning money. Extrinsic motivational is external in the nature. The most well-known and the most debated motivational is money. Other examples of extrinsic motivation include employee of the month award, benefit package, bonus and organized activities (Armstrong 2012).

\subsection{Motivator factors}

Motivator factors are factors that are intrinsic to the job, such as the content of the work itself and the availability of opportunities for responsibility, advancement and recognition for achievement (Santrock, 2009).

Hygiene factors are extrinsic to the job and relate to the environment in which the job is performed. Such factors include the organization's policy and administration, working conditions, salary, supervision and interpersonal relations. Herzberg argued that the extrinsic aspects of work (the hygiene factors) could not provide a source of motivation for employees but could, if 'bad', provide a source of dissatisfaction and thus demoralize employees. Hygiene factors should be seen as the prerequisite to allow the motivating factors to influence employee's motivation. In a situation where there were 'good' hygiene factors, the employee would be in a state of 'no dissatisfaction'. The motivator factors, which Herzberg (1959) described as complex factors 
leading to this sense of personal growth and self-actualization, would then reflect employee motivation hence increase job satisfaction and productivity. As a consequence, in order to motivate workers towards higher productivity, while it is important to ensure that the hygiene factors are correct, the manager must manipulate the motivators by attending to job-content issues for example job-enrichment (Sisk, 2009). Even though a lot has been written on motivation, this subject is not clearly understood and more often than not poorly practiced. To well comprehend how motivation can impact on employee's performance, one must identify with human nature. In as much as motivation impacts on employee performance, there is need to blend the appropriate motivational tools with effective management and leadership to achieve this goal. Even though the fact that motivation is very important to determine employee's ability, are other factors such as the resources given to an employee to perform his or her job. For this reason, successful work performance can arise from a variety of motives. For instance, one salesperson may be motivated by the commission earned on sales, while the other may be more concerned about achieving sales targets. This creates a fine distinction in the subject matter because motivation to enhance performance varies from person to person and from organization to organization (Daft, 2009)

\subsection{Employee Performance}

An effective performance management action is an important tool for employee motivation for optimal performance. However, it is not an enough condition for effective performance management. The most important issue with any performance management system is how critically it is taken and how devotedly it is used by managers and employees. (Pulakos 2009, 103) Performance management is all about perfection, synchronizing, upgrading to create value for and from customer with the result of economic value creation to stockholders and owners. The expansion of performance management is clearly very large, which is why performance management must be viewed within an enterprise as a tool to improve on employee motivation for high performance. (Cokins 2009, 9) Efficient management of performance requires a strong apprehension of the performance domain. That is, apprehending the obligation and projects that are part of the job description within a company or organization

Once you have full skills of what the job requires, you have the basis for assessing and enhancing performance. This is the foundation for assessing and improving performance within a company. When this is lacking, the outcome is a missing link in evaluating employee performance and the possibility of improving on the employee performance within the organization. Moreover, there is also the missing link in assessing employee's performance in relationship to other colleagues in the same job description (Robert 2003, 7).

\subsection{Job satisfaction}

In general job satisfaction as the singular assertiveness concerning the numerous characteristics of their works. Job satisfaction as the emotive happiness that outcomes from the evaluation ones work as attaining or simplifying the accomplishments of one's job importance (Lock, 1969). The observed work happiness produces progressive sentiment amongst individuals which in casual signify optimistic emotive reply in the direction of want for authority. The author additional discuss that satisfaction is attained as ones understands the importance of work standards to achieve ones elementary requirements. For the individuals working life skill job satisfaction is one of the important factors. Job satisfaction significance is connected to an individual getting enough extrinsic and intrinsic benefits to inspire the workers to stay and continue to expend a huge extent of period and accomplishing their responsibilities. Many scholars agree that job satisfaction is a direct on employee performance at numerous levels in an organization.

It is one of the most important broadly debated topics in organizational manners, organizational management, staffs and human capital management. In simple word job satisfaction is sensation decent the job performed, combine with the organization mission and vision and a state of awareness Lewis et al. (2002). According to Steijn, B (2002) job satisfaction is an enjoyable sensitivity that outcomes from the insight that one's job permit or achieve of one's personal work standards. Persons want to accomplish their quantifiable capital through the work completed intentionally or unintentionally. Job satisfaction is the amount to which employees think significantly about their work (Pool, S.W,1997).

Job satisfaction is an emotive reply to ones work as well as the social and physical situation of the job environment. It is expected to be greater for workers who observe incentive involvement equilibrium in their connection with engaging organization. In sum up job satisfaction is the outcomes of several arrogances influenced by a personnel toward his or her work. These job satisfaction attitudes may be linked to work features such as job security, environment of work, salaries, and quick abstraction of complaints, job surroundings, and chance for advancement, and chances for involvement in decision building and other pleasure of marginal remunerations. Any type of industry or enterprise the job satisfaction of whole lab our force play a key role and with a collection of pleased employee organization can effectively implement their policy. Numerous observed investigations have revealed that job satisfaction has direct effect on the employees job performance at many level in an organization. Job satisfaction is connected to worker performance and motivation (Kiviniemi et al, 
2002). According to Meyer et al. (2002) explained that job satisfaction is an approach originated from worker sensitivities of their works or job environment and mentions to the degree to which an individual enjoys his or her work. It is an attitude very delicate to the features of the setting in which its learning.

\subsection{Performance in organization}

Performance in organization can be divided into organizational performance and job performance (Otley 1999, 363-382). According to Otley, the performance of organization is subjected to the performance of employee's job performance and other components such as environment of the organization. The difference between organizational and job performance is apparent; an organization that is performing well is the one that is successfully reaching its objectives, in other words: one that is in effect carrying out an appropriate plan and job performance is the single outcome of an employee's work. Furthermore, high job performance is the ability of the employee himself. The employee must be able to give better results and also have a high productivity (Hunter, 1986, 72 - 98).

\subsection{Job performance}

A good employee performance is necessary for the organization, since an organization's success is dependent upon the employee's creativity, innovation and commitment (Ramlall 2008, 128). Good job performance and productivity growth are also important in stabilizing our economy; by means of improved living conditions, high wages, increase in the availability of goods for consumption, etc (Griffin et al 1981) Griffin et al. also argue that therefore research of individual employee performance is important to society in general.

Employee production and employee job performance seems to be related; performance in some cases is measured as the number and value of goods produced. However, in general, productivity is associated with production-oriented terms (e.g, profit and turnover) and performance is linked to efficiency or perception oriented terms (e.g. supervisory ratings and goal accomplishments (Griffin et al 1981, 655-664).

\subsection{Performance Improvement}

It is a response to make services of an organization better, affordable and faster. It seeks to rectify any problems that exist and build upon those performance levels that are already good (Katz and Green, 1997). According to Katz and Green (1997, pp.: 2000) performance improvement involves the resolution of performance problems and the exploitation of performance opportunities. Problems may be related to service, practice or governance. Performance opportunities consist of those occasions when, although the performance target is adequate, an opportunity exists to improve the outcome of the service or process by which the service is delivering.

\subsection{Performance Appraisal Methods:}

The most commonly used performance appraisal methods include: Essay appraisal: This merely requires the rater to write a series of statements concerning an individual's strengths, weaknesses, past performance and potential for promotion. Graphic rating scale: in which the rater assess an individual on factors such as initiative, dependability, cooperativeness, attitude and quantity of work. Checklist method: in which the rater does not evaluate performance but merely records it on a series of questions concerning the employee's behavior, the rater checks yes or no responses e.g. (a) does the individual perform his or her job, (b) shows superior ability to express him or herself. Critical incident: appraisal in which the rater is asked to keep a written record on incidents that illustrates both positive and negative behavior of the individual being rated. In this method, the individual's actual behavior and not personality traits, is discussed. Ranking method: This is used when it becomes necessary to compare the performance of two or more individuals. Management by objective (MBO): approach or performance evaluation, which is based on converting organizational goals and objective for individuals (Obserg, 1972), Maiser (1976) suggests that the above performance appraisal method could be communicated to the appraise using the following methods. Tel and sell method: in which the ratter lets the employee know how he or she is doing, gets the employee's acceptance of the evaluation, and has the employee agree to plan of improvement. This method according to Maier is most likely to be successful with new, young employees and with employees who are in a new assignment. People in these positions are more likely to have insecurity that can result from inexperience and usually are more anxious to receive the helpful advice of a more experienced person. Tell and listen method: the general approach with tell and listen method is for the rater to communicate the evaluation and then wait for a response from the employee. Basically, the valuation is conducted in two parts. During the first part, the employee's strong and weak points are covered, during the second, the employee is encouraged to disagree and express his or her feelings about the appraisal. Problem solving method: according to Maier, the first two methods tell and sell and tell and listen methods place the rater in the position of being a judge and force the individual being evaluated into a defensive position. However, the problem method is to take the reviewer out of the role of a judge and make him or her helper and a friend. 3600 appraisal method: this kind of method ensures that not only the superior that appraises the subordinate but also 
the subordinate also appraises the superior. Colleagues also appraise colleagues and individuals who appraise themselves and all the appraisals are used to arrive at the final appraisal outcome after calculating the average.

\subsection{Importance of Motivation}

Motivation is necessary for employee performance. If people do not feel inclined to engage themselves in work behavior, they will not put necessary efforts to perform well. However performance of an individual in the organization do not only depends on motivation instead there other factors besides the level of motivation which include abilities, sense of competence, role perception and resources.

Motivation seems to be one of the most important tools for increases productivity and retaining employees. Organizations that design motivation systems are not only meant to encourage employees to perform in the most effective way but also to attract potential candidates. One of many ways to motivate and retain employees is by giving traditional rewards and monetary benefits, compensation incentives to reward good performance (Memmott and Growers, 2012).

\subsection{Theoretical Review}

Various scholars have developed several motivation theories approaching motivational problem but all emphasizing on similar set of relationships which include individual, his needs, his perception on how to satisfy his needs, and weather his needs satisfaction is equitable. All theories are not unified thus may work only in a particular context. In this study Maslow's hierarch of needs, Herzberg's Motivation theory, McGregor's Theory $\mathrm{X}$ and $\mathrm{Y}$ will be discussed to find out importance and implications in motivating employees.

\subsection{Maslow Hierarchy of Needs}

The first theory of motivation which is used as a theoretical base for this study is Abraham Maslow's motivation theory. Abraham Harold Maslow (1908 - 1970) is an American psychologist who is well-known for his theory of Hierarchy of Needs. The theory illustrates five different stages of human needs in a hierarchic order, starting from the most basic to the most complex ones. In a survey "Review of General Psychology" published in 2002, Maslow was named among the tenth most famous psychologists in the 20th century (Haggbloom, Warnick, Warnick, Jones, Yarbrough, Russell, Borecky, McGahhey 2002)

There are some needs that are fundamental to human beings, and without their existence nothing else matters. We - living persons - consider needs as a motivator. We always start with the lowest level of needs (Skemp-Arlt \& Toupence 2007) and strive for satisfaction fulfillment; once achieved, we are then looking to satisfy higher needs. In other words, "a person cannot move to the next level of needs without satisfying the previous level" (Maslow 1954) Maslow's Hierarchy of Needs is often described in a pyramid shape with the largest and most elementary levels of need at the bottom, and the need for self-actualization at the top (Steere 1988). "Maslow used the terms 'physiological', 'safety', 'belongings' and 'love', 'esteem', and 'selfactualization' to describe the pattern that human motivations generally move through. The goal of Maslow's theory is to attain the highest level offstage: self-actualization needs" (McEwen \& Wills 2014).

The most basic and essential four layers of Maslow's Hierarchy of Needs pyramid are called "deficiency needs" or "d-needs": physiology needs, safety needs, love and belongings, and esteem. If there is a deficiency on this level, an individual's all behaviors will be directed to content the deficits (Cherry 2015). Furthermore, if these "d-needs" are not met - with the exception of physiology needs: a fundamental level of need which must be fulfilled with satisfaction in the first place - the individual will feel nervous and scared. For example, if you have not slept well or eaten adequately, you will not be interested in your belongings desires.

It is suggested by Maslow that the most essential level of needs must be met and achieved before a person moving to satisfy higher levels of needs (Goble 1970). In addition, the "d-needs" itself classified into basic needs (including physiological and safety needs) and psychological needs (including love and belonging and esteem) (McLeod 2007, 2016). The Hierarchy of Needs starts with the lowest level of need: physiology needs (SkempArlt et al. 2007). Physiological needs including vital necessities for human existence, such as; air, water, food, and other living needs. Physiological needs are considered to be the most important because without satisfying it first, the desire for other needs is not a matter of concern. Without food, a human body cannot function well; if you are hungry, all your activities will be oriented and forced to find food; "employers who pay at least a minimal living wage will meet these basic employee needs" (Silberstein 2017). Therefore, physiological needs should be met first. Once an individual's physiological needs are achieved and somewhat satisfied, the person drives the desire towards his or her safety needs (Skemp-Arlt et al. 2007). It includes, for instance, the personal security: of body, of health and wellbeing, of morality, and of family; the job security: of work opportunity, and of employment; and the financial security: of property, and of resources. In the world nowadays, it is a concern when the need for safety is day by day increasing. It is not just about having a place to live, feeling certain and being free from the threat of danger and pain. People feel unsafely due to such reasons as natural disaster, war, violence, abuse, or economic instability. 
This level is more likely to be appeared in children as they normally need the feeling of being secured. In organization, "employers can meet these needs by ensuring employees are safe from phys-ical, verbal or emotional hazards and have a sense of job security" (Silberstein 2017) The next level of needs is love and belonging (Skemp-Arlt et al. 2007), which belongs to human's psychological needs. "Humans need to love and be loved - both sexually and non-sexually - by others" (Goble 1970). According to Maslow, when an individual's basic needs are fulfilled, their need is interpersonal, involvement, and acceptance. This is the need to be social, to have friends, and relationships. It can be the involvement in a group of co-workers, clubs, student organization, hobbies group, or a person's own gang; or the connections with family, close friends, colleagues, and neighbors. We cannot deny the important role of love and belonging needs in human's life, as there are evidences of people experiencing from loneliness, anti-socialization, autism or even depression in the deficient of this element. Respectively, for employers in business aspect, being able to create a satisfactory reward system and implement organizational program in which employees are actively take part in can help fulfill and satisfy these needs of employees (Silberstein 2017).

The fourth level mentioned by Maslow in the Hierarchy of Needs is esteem needs. "All people in our society have a need or desire for a stable, firmly based, usually high evaluation of themselves, for self-respect, and for the esteem of others" (Maslow 1954, Stephens 2000). Consequently, this level of needs is categorized into two types, which can be defined by the term "self-respect" and "esteem". Self-respect refers to "the desire for strength, for achievement, for adequacy, for mastery and competence for confidence in the face of the world, and for independence and freedom" (Maslow 1954). This level is achieved when a person feel satisfied and enjoyable with what they have completed, like simply by feeling positively, and living a meaningful, valuable and on-purpose life. Likewise, esteem portrayed the desire to be accepted and valued by others. And only by satisfying the "desire for reputation or prestige, status, fame and glory, dominance, recognition, attention, importance, dignity, or appreciation" this esteem needs will be fully achieved (Maslow 1954, Brembeck 1991).

Finally, self-actualization: which is classified as the "being needs" or "b-needs - is the highest level in Maslow's Hierarchy of Needs. "What a man can be, he must be" (Maslow 1954). This level illustrates the need of "to become everything that one is capable of becoming" (Hagerty 1999): to be aware of and achieve a person's full potential. In other words, they will try to do everything to the best of their ability. When a person has reached the state of self-actualization, they tend to be individualistic, focusing more on themselves and having a desire to widen knowledge, acquire new skills, take on new responsibilities, experience more new challenges, and act in a way that will take them to attain their desired life goals. According to Maslow, in order to completely achieve this level of needs, an individual must not only achieve and satisfying the previous needs, but also master them (Maslow 1954; McLeod 2007, 2016).

\subsection{Hygiene Theory (Herzberg 1968)}

This is another motivational theory developed by Fredrick Herzberg who conducted intensive study on the experience and feelings of about 200 engineers and accountants in nine different companies in United State of America concerning their previous jobs. Theorist found that there were two categories of needs essentially independent of each other affecting behavior in different ways thus are maintenance or hygiene factor and motivational factors. Hygiene Factors these include several factors like company policy and administration, technical supervision, interpersonal relationship with peer and subordinates, salary, job security, personal life, working conditions and status. These are not intrinsic part of a job, but they are related to conditions under which a job is performed.

They produce no growth in a workers output they only prevent losses in workers performance due to work relations. These maintenance factors are necessary to maintain reasonable level of satisfaction of employees, increase beyond this level will not provide any satisfaction while decrease below this level will dissatisfy employees. Motivational factors are capable of having positive effect on job satisfaction often resulting in an increase in one's total output. These include achievement, recognition, and advancement; work itself, possibility of growth and responsibility. Most of these factors are related to job contents. An increase in these factors will satisfy the employees; however any decrease will not affect their level of satisfaction. Since these increase the level of satisfaction of employees may be used in motivating them for higher output. Implication of Herzberg model is based on the fact that most of the people are able to satisfy their lower order needs considerably. The model has been applied in the industry and has given several new insights. One of the insights is job enrichment which involves enrichment of jobs in such a way that they have more motivators than before, the idea behind job enrichment is to keep maintenance factor constant or higher while increasing motivational factors (Prasad, 2005). The theory alerts human resource managers that an employee cannot be motivated by a single motivation factor instead a combination of intrinsic motivation factors like promotion, career achievement, recognition as well extrinsic factors such as salary, medical benefits, transport benefits and working condition are required to achieve better performance. 


\subsection{McGregor's Theory $X$ and $Y$}

The theory involves assumptions such as generalization and hypotheses relating to human behavior and nature. McGregor presented assumptions that could predict human behavior in two opposite point as follows;

2.13.1. Theory $\mathbf{X}$; Management is responsible for organizing the element of productive enterprise that is money. Material, equipment, people in the interest of economic ends, it also assume that without active intervention by management, people would be passive even resistant to organization needs, Furthermore this theory assume that an average man is by nature indolent, man lacks ambition, dislikes responsibility and prefer to be led, lastly the theory assume that a man is inherently self-centered, indifferent to organization needs and resistant to change by nature.

2.13.2, Theory $Y$ : The expenditure of physical and mental effort in work is natural as play or rest, second assumption states external control and threat of punishment are not the only means for bringing about effort towards organization objectives, thirdly commitment to objective is a function of the reward associated with achievement. Fourth assumption state that the average human being learn under the proper conditions not only to accept, but to seek responsibility. Furthermore the capacity to exercise a relatively high degree of imagination, ingenuity, and creativity in the solution of organizational problem is widely, not narrow distributed in the population and lastly under the conditions of modern industrial life, the intellectual potentialities of the average human being are only partially utilized. Theory X and Y implies that management should greatly consider kind of people has in the organization especially when undertaking management functions such as planning, directing, apprising and controlling.

\subsection{Vroom's Expectancy theory}

The first component in the equation is expectancy, which is defined as a person's belief that their effort will resulted in desired outcomes, such as performance or success. It is also a person's evaluation of what kind and how much effort should be put in order to achieve better results or higher performance. For example, an employee working in the customer services department believes that if he/she tries harder, the work performance will lead to customer satisfaction. When the employee has a strong feeling of it and is aware that he/she is able to accomplish the goal, then he/she will be likely to put more effort to work. In this way, we say he/she has high expectancy. The second component - instrumentality - refers to a person's belief that his/her performance is linked to later results, such as reward or punishment. For instance, if a person believes that his/her hard-work will be recognized and resulted in rewards, he/she is likely to put more effort to work. Finally, valence component demonstrates a person's perception about the amount of reward or punishment received as a result of performance. If a person feels that the reward or punishment is well-earned with his/her effort and performance, he/she will put more effort to achieving it (Skempt-Arlt et al 2007; Scholl 2002). Force, which indicates a person's motivation to perform a set of activities, is the result of the three components. "In general, people will work hard when they think that it is likely to lead to desired organizational rewards" (Skempt-Arlt et al 2007). "Vroom thought that people are motivated to work toward a goal if they believe the goal is worthwhile and if they perceived that their efforts will contribute to the achievement of that goal" (Moran 2013). In short, the theory implies that when a person reaches a high level of all components in the equation, he/she will be highly motivated and put more effort into attaining the desired outcomes.

\subsection{The effects of motivation on employees' performance}

The motivation theorists such as Maslow (1946), Herzberg (1968), Alderfer (1972) and McClelland (1988) have suggested specific things that managers can do to help their subordinates become self-actualized, because such employees are likely to work at their maximum creative potential when their needs are met. They agree that by promoting a healthy workforce, providing financial security, providing opportunities to socialize and recognizing employees $^{\text {ee }}$ accomplishments help to satisfy the employees ${ }^{\text {ee }}$ physiological needs which in turn also increase their performance. These authors (Koch, 1990; Stuart, 1992) all stated that recognition of a job well done or full appreciation for work done is often among the top motivators of employee performance and involves feedback. Positive feedback follows the principles advocated in Reinforcement Theory, which states that behavior is contingent on reinforcement. Examples of positive reinforcement in this context may include workplace visits by top executives to high-performance employees, personal handwritten notes of thanks accompanying paychecks, and telephone calls by top executives to employees at home (Knippen and Green, 1990).

Theories such as equity has some important implications for ways of motivating people by not underpay, overpay and presenting information about outcomes in a thorough and socially sensitive manner. It states that, companies that attempt to save money by reducing employees ${ }^{\text {ee }}$ salaries may find that employees respond in many different ways to even the score; those that overpay some employees as a useful motivational technique to increase performance may later realized that when you overpay one employee, you are underpaying all the others. When the majority of the employees feel underpaid, they will lower their performance, resulting in a net decrease in productivity and widespread dissatisfaction. Hence, the conclusion is that managers should strive to 
treat all employees equitably; and This suggestion follows from research showing that people's assessments of fairness on the job go beyond merely what their outcomes and inputs are to their knowledge of how these were determined, that is, to their sense of procedural justice (perceptions of the fairness of the procedures used to determine outcomes). Osei (2011), also agrees with the equity theory that, one of the fundamental issues that is sensitive and critical which can make or unmake any organization is wage or salary determination. Justice, fairness and equity in salary determination, to a large extent, put to rest all the traumas a ny individual or any organization may experience, and that is highly motivational enough to assess the optimal usage of time and energy. Also, theory such expectancy has several important implications for ways of motivating employees by clarify people's expectancies that their effort will lead to performance, that is by training employees to do their jobs more efficiently and so achieve higher levels of performance from their efforts and linking valued rewards and performance by specifying exactly what job behaviors will lead to what rewards.

It is possible for employees to be paid in ways directly linked to their performance such as through piecerate incentive systems, sales commission plans or bonuses. Locke (1968), goal setting theory believes that you can achieve effective performance goals by assigning specific goals; difficult but acceptable performance goals; and providing feedback concerning goal attainment. He further indicated that giving praises, Management by Objectives (MBO), and job-design increases employees ${ }^{\text {ee }}$ performance. Praise is motivator (not hygiene) because it meets employees ${ }^{\text {ee }}$ needs for esteem, self-actualization, growth and achievement. It is most powerful, less expensive, and simplest, yet the most underused motivational technique. To motivate people to high-levels of performance, objectives should be difficult but achievable, observable and measurable, specific, with a target date, anticipatively set when possible and accepted by employees. Employee who meet their objectives should be rewarded through recognition, praise, pay raises, promotions etc. Many organizations now link pay to meeting goals (Lussier, 2005) and the way the first step in organization design is job design - the process by which managers decide how to divide tasks into specific jobs, for example, McDonaldisation (Jones et al, 2000).

\subsection{Empirical Literature Review}

Several researchers have examined factors that motivate workers and their subsequent impact their employee motivation. This section presents a review of some most recent empirical studies on employee motivation and in various organizations including Health. Aiyetan and Oltuah (2006) conducted a research on the relationship between job performance and employee motivation of workers in FGH purpose was to identify a number of motivational schemes that enhance the performance of two types of workers: professional Health workers and Administrative(supportive staff)workers.

The study used two sets of questionnaires: one set was administered on management staff and the other on non-management staff (operatives). The study revealed that salaries paid to all staffs in the study were below the stipulations of the employee motivation it further showed that all staffs are rarely promoted, and operatives prefer financial incentives to non-financial incentives. The study recommended that increases in salary via promotion, overtime allowances and holidays with pay should be used as motivators (financial incentives) for increase in performance of all workers in FGH.

The three motivating factors were interpersonal relationship, workplace environment and interesting work, all of which have the potential to motivate employees at higher levels. For long-term motivation, job related factors such as meaningful work, flexible working hours, and friendly social gestures were found to be effective motivators, while monetary, social gathering, tangible items such as awards, certificates and gifts were most effective motivators for short-term. The purpose was to assess motivation to perform among healthcare workers in Hospital healthcare facilities.

Its purpose was to examine factors that motivate employees in order to have increased performance within the Hospital. The study found that employees at Ultimate in FGH had an overall fair job satisfaction. The employees are not satisfied with their current salary situation at the Hospital which illustrate that financial motivation was important within a Hospital the findings equally showed that majority of the employees are motivated most to perform when they receive non-financial rewards. Also, majority of the employee showed a great intrinsic value for higher performance. Finally, the study recommended that the management at Ultimate companion limited should use multiple motivational strategies in order to achieve greater performance from the employees

\subsection{Conceptual Frame Work}

The model below illustrates some of the motivating factors which affect employees' motivation. These factors will form the independent variables of the study and will be manipulated to positively or negatively affect the dependent variable, which is employee motivation. These independent variables have been broadly covered in the literature review. 


\begin{tabular}{l} 
Independent Variable \\
\hline Working \\
\hline Benefits \\
\hline Empowerment \\
\hline Recognition
\end{tabular}

\section{RESEARCH DESIGN AND METHODOLOGY}

To conduct this research the researcher has employed explanatory research design. This research design has been used to explain the effect and relation that exist between the aspects of employee motivation and job performance of the employees. Moreover, it is used to explain the cause effect relations and used to generate many ideas. To reach on appropriate conclusion about the issue and in order to answer research hypothesis the necessary data has been collected through quantitative approaches. The quantitative approach would allow the researcher to measure and analyze statistical data.

Fiche General Hospital permanent employees would be the main targets of this study. The Fiche General Hospital operating department are, Medical Department, Specialist/Clinical/, Midwifery, Nursing, Pharmacy, Radiology, Mental Health, HRM and Finance Department. The total number of employee in Fiche General Hospital operating are 351 from which adequate samples would be selected using appropriate method of sample size determination. To determine representative sample from the Fiche General Hospital of the 351 employees, the researcher has used Yamane 1976 formula and the sample size was 187 employees.

The type of data used for this was primary data. This data were collected through questionnaires from target respondent and interview was also used to collect primary data from authorized body of Fiche General Hospital. In order to know the effect of employee motivation on job performance in Fiche General Hospital, the researcher use the multiple regression models as follows

$Y=\beta 1 X 1+\beta 2 x 2+\beta 3 X 3+\beta 4 X 4+\beta 5 \times 5+\beta 6 X 6+\beta 7 x 7+\beta 8 \times 8+\beta 9 X 9$

Where;

Y -Job performance

$\mathrm{X} 1$-Benefit package

$\mathrm{X} 2$-Empowerment

X3-Recognition

$\mathrm{X} 4$ - Working condition

$\mathrm{X} 5$-Education

X6-Gender

X7-Experience

X8-Age

X9-Salary

Where; $\mathrm{Y}$ is the job performance

$\mathrm{e}=$ is random error

$\mathrm{B} 1, \mathrm{~B} 2, \mathrm{~B} 3$ up to $\mathrm{B} 9$, refers to the coefficient of their respective independent variable which measures the change in the mean value of $\mathrm{x}$, per change in respective independent variable.

\section{DATA ANALYSIS AND INTERPRETATION}

4.1. Descriptive analysis of motivational factors

Table 4.1: Analysis of employee benefit package

\begin{tabular}{|c|l|r|r|}
\hline No & \multicolumn{1}{|c|}{ Benefit package practices } & Mean & Std. D \\
\hline 1 & In FGH I have got adequate payment for the responsibility I discharged & 2.13 & 1.285 \\
\hline 2 & FGH employee benefit package compared with similar jobs in other companies is fair & 3.69 & 1.640 \\
\hline 3 & In FGH, the reward programs are timely up date has encourage me for better performance & 2.19 & 1.449 \\
\hline 4 & In FGH, I am motivated as a result of benefit package offered for me & 3.41 & 1.381 \\
\hline 5 & $\begin{array}{l}\text { In FGH I am encouraged for the practices of training and development programs } \\
\text { employee benefit package. }\end{array}$ & 3.37 & 1.285 \\
\hline 6 & An employee compensation and benefit package of FGH is attractive \& retains me & 2.78 & 1.248 \\
\hline
\end{tabular}

Source: Survey, 2019 
The mean score of employee benefit package sub factors are range between 3.69 and 2.13, as presented in table 4.1 above. The mean score was higher for the equivalence of Fiche General Hospital employee benefit package with similar jobs in other companies is 3.69 , followed by the employee motivation level as a result of benefit offered by Fiche General Hospital is 3.41 and the level of training and development practices as employee benefit package in Fiche General Hospital is 3.37 correspondingly. This implies that the majority of participants scored highest level of agreement (strongly agree) about equivalence of employee benefit package with similar jobs in other companies raised questions.

\section{Table 4.2: Employee empowerment practices}

\begin{tabular}{|l|l|c|c|}
\hline No & Empowerment practices & Mean & Std. D \\
\hline 1 & In FGH I normally get sufficient resource to do my job & 2.16 & 1.253 \\
\hline 2 & In FGH I have significant autonomy in determining how I do my job & 2.57 & 1.341 \\
\hline 3 & In FGH I have control over those aspect of my job for which I am accountable & 2.88 & 1.334 \\
\hline 4 & In FGH I have mastered skills necessary for my job & 4.21 & .734 \\
\hline 5 & In FGH there is clear system of handling employee dissatisfaction & 2.14 & 1.193 \\
\hline 6 & In FGH, I have involved in decisions making that affect my work. & 3.51 & 1.459 \\
\hline \multicolumn{2}{|l}{} & $\mathrm{N}=179$ \\
\hline
\end{tabular}

Source: Survey, 2019

As presented in Table 4.2: the mean value of employee empowerment practices sub factors study result differs from 4.21 to 2.14 and it would be described from general to specific as follows. The level of employee mastered skills after working in Fiche General Hospital was scored higher mean 4.21; followed by the level of employee involvement in decisions making that affect their work has been the next highest mean scored 3.51. This implies that majority respondent levels of agreement have been strongly agreed with raised statement of item $4 \& 6$. This means that there are good practices of item $4 \& 6$ in Fiche General Hospital.

However, with the level of employee control over those aspect of their job for which they are accountable has the mean score of 2.88 , followed by the level of employee autonomy in determining how they do their job has 2.57 mean scores; the level of resource allocated for employees so as to accomplish their job has 2.16 mean scores and the availability of clear system of handling employee dissatisfaction practices has 2.14 mean scores with the level of disagreement respectively in Fiche General hospital.

Table 4.3: Employee recognition practices

\begin{tabular}{|c|l|r|r|}
\hline No & \multicolumn{1}{|c|}{ Employee recognition practices } & Mean & $\begin{array}{c}\text { Std. } \\
\text { D }\end{array}$ \\
\hline 1 & In FGH I have got relevant \& timely recognition for my achievements at work. & 2.67 & 1.539 \\
\hline 2 & The way I am noticed when I do a good job enhance me for more job performance & 2.34 & 1.382 \\
\hline 3 & $\begin{array}{l}\text { The praise I get for doing a good job in FGH has positive influence on my job } \\
\text { performance }\end{array}$ & 2.45 & 1.307 \\
\hline 4 & The pride I get for the a job well done in FGH has motivated me & 2.61 & 1.367 \\
\hline 5 & In FGH I get the chance to be important in the eyes of others & 2.11 & 1.197 \\
\hline \multicolumn{1}{|c|}{ Source: Survey, 2019 } &
\end{tabular}

According to table 4.3, the average response of the five items of recognition practices shows small variation and range between 2.67 and 2.11 in deductive form as follows. According to the measurement of midpoint three on the five-point Liker scale and the level of employee achievements recognition practice relevancy \& timely has the higher mean score of 2.67 ; followed by the level of employee motivation for the pride they get for the a job well done has the mean score of 2.61; the level employee praise influence on job performance has the mean score of 2.45; the way employee are noticed when they do a good job has the mean score of 2.34 and the chance employee get to be important in the eyes of others when doing good job has the mean score of 2.11 respectively shows low or disagreement in Fiche General hospital. This implies that the majority of respondents scored lowest in the scale (disagree). This shows there is poor employee recognition practices particularly with the chance employee get to be important in the eyes of others when doing good job in Fiche General hospital. 
Table 4.4 Fiche General Hospital Employee working condition

\begin{tabular}{|c|c|c|c|}
\hline $\mathrm{Nc}$ & Fiche General Hospital working condition & Mean & $\begin{array}{l}\text { Std. } \\
\text { D }\end{array}$ \\
\hline 1 & My workplace has a warm, friendly and a pleasant atmosphere that I am happy with. & 2.24 & 1.138 \\
\hline 2 & My manager recognizes and appreciates my achievements and that inspires me to work harder. & 2.37 & 1.101 \\
\hline 3 & $\begin{array}{l}\text { There is adequate supply of stock and equipment that enables me to provide the required } \\
\text { standard of service to the patients. }\end{array}$ & 2.21 & 1.259 \\
\hline 4 & My workload is sometimes increased because my co-workers are absent & 3.45 & 1.209 \\
\hline 5 & I am given sufficient information to protect myself against hazards that may result in my work. & 3.98 & .909 \\
\hline 6 & $\begin{array}{l}\text { Our managers keep us informed on regular basis about important issues and new developments } \\
\text { regarding the hospital and its management. }\end{array}$ & 5.43 & 1.456 \\
\hline
\end{tabular}

Source: Survey, 2019

The mean responses of all items of employee working condition are range between 2.21 and 3.98, as presented in table 4.4 above. With regard to getting sufficient information to protect against hazards in the wok area has highest mean score 3.98, followed by change in employee workload is 3.45 and the level of getting relevant information from manager practices is 3.43. This suggests that the majority of members scored higher level of agreement (agree) about item 5, 4 \& 6 raised questions. This means these items mean shows there are good employee working condition in Fiche General Hospital. On the other hand, the level of employee recognition and appreciation for their achievements has the mean score 2.37 , followed by the employee workplace atmosphere has the mean score of 2.24 and adequacy of working equipment supply has the mean score of 2.21, shows the lower level of agreement, which is disagree respectively in Fiche General hospital.

4.2. Descriptive analysis of employee job performance Table 4.5: Fiche General Hospital employee Job performance

\begin{tabular}{|c|l|c|c|}
\hline No & \multicolumn{1}{|c|}{ Employee Job performance } & Mean & $\begin{array}{l}\text { Std. } \\
\text { D }\end{array}$ \\
\hline 1 & The employee recognition practices of FGH improved my job performance & 2.68 & 1.281 \\
\hline 2 & $\begin{array}{l}\text { The employee empowerment practices in FGH has encouraged me for better job } \\
\text { performance }\end{array}$ & 2.26 & 1.413 \\
\hline 3 & The employee benefit package practices of FGH boosted my job performance & 2.55 & 1.341 \\
\hline 4 & The overall working condition of FGH enriched my job performance & 2.46 & 1.302 \\
\hline 5 & $\begin{array}{l}\text { The job performance standard criteria of FGH has motivated me for better job } \\
\text { performance }\end{array}$ & 2.17 & 1.260 \\
\hline 6 & In FGH there is employee motivation practices for better job performance & 2.61 & 1.407 \\
\hline 7 & In FGH I have significant opportunity for independence in how I do my job & 2.31 & 1.411 \\
\hline & & \multicolumn{2}{|c|}{$\mathrm{N}=179$} \\
\hline
\end{tabular}

Source: Survey, 2019

As presented in table 4.5: the mean value of employee job performance sub factors study result differs from 2.68 to 2.17 and it would be also analyzed from general to specific as follows. The employee recognition for better job performance practices has higher mean 2.68; followed by employee motivation practices for better job performance has the next higher mean score.2.61; employee benefit package for superior job performance has 2.55 mean scored; the level of working condition for healthier job performance has 2.46 mean scored; the level of employee independence in how they do their job has 2.31 mean scored; employee empowerment practices for superior job performance has 2.26 mean score and the level of employee satisfaction about Fiche General Hospital job performance standard criteria. The mean scores indicate that all the participants have been disagreed to sub factors of job performance question raised in association with Fiche General Hospital employee motivational practices.

Table 4.6: Comparative analysis of overall study variable

\begin{tabular}{|c|l|c|c|c|c|}
\hline No & & Mean & $\begin{array}{c}\text { Rank } \\
\text { Mean }\end{array}$ & Std. D & $\begin{array}{c}\text { Variability } \\
\text { Rank }\end{array}$ \\
\hline 1 & Job performance & 2.4008 & $1^{\text {st }}$ & .66918 & $5^{\text {th }} \mathrm{t}$ \\
\hline 2 & Recognition Practices & 2.4358 & $2^{\text {nd }}$ & .57127 & $3^{\text {rd }}$ \\
\hline 3 & Empowerment practices & 2.9125 & $3^{\text {rd }}$ & .59684 & $4^{\text {th }}$ \\
\hline 4 & Benefits package & 2.9283 & $4^{\text {th }}$ & .50278 & $2^{\text {nd }}$ \\
\hline 5 & Working Condition Practices & 2.9404 & $5^{\text {th }}$ & .49421 & $1^{\text {st }}$ \\
\hline \multicolumn{2}{|l|}{$\mathrm{N}=179$} \\
\hline
\end{tabular}

Source: Survey, 2019 
As showed in table 4.6: the overall mean score of independent variables of the study were ranging from 2.401 to 2.940 with their corresponding standard deviation have been ranging from 0.66918 to 0.49421 . Relatively, the mean score was higher for working condition practices 2.9404 ; followed by benefits package 2.9283; empowerment practices 2.9125; recognition practices 2.4358 and job performance 2.4008 respectively. This implies that the below the average respondents' has been disagree. In general all of this study finding shows there is poor practices of employee motivational practices for their better job performance in Fiche General Hospital.

The job performance has the highest standard deviation 0.66918 ; followed by empowerment practices with value of standard deviation 0.59684 ; recognition practices 0.57127 , benefits package 0.50278 \& working condition practices.49421 respectively. According to the observed standard deviation value of table 4.7; shows there is high variability of respondent rating of job performance with strongly disagree, disagree, neutral, agree \& strongly agree at Fiche General hospital.

\subsection{Correlation Analysis}

With an objective of measuring the relation between motivational factors and employee job performance in Fiche General Hospital the researcher has used Pearson correlation analysis as follows.

Table 4.7: Correlation matrix of employee job performance

\begin{tabular}{|c|c|c|c|c|c|c|c|c|c|c|c|}
\hline & & JP & $\mathrm{BP}$ & EP & RP & $\mathrm{WC}$ & A & Edu & Ex & $\mathrm{G}$ & $\mathrm{Sa}$ \\
\hline \multirow[t]{2}{*}{ Job performance } & Corr. & 1 & $.648^{* *}$ & $.752^{* *}$ & $.769^{* *}$ & $.704^{* *}$ & -.035 & $.167^{*}$ & .059 & .008 & -.072 \\
\hline & Sig. & & .000 & .000 & .000 & .000 & .645 & .026 & .436 & .915 & .341 \\
\hline \multirow[t]{2}{*}{ Benefits package } & Corr. & $.648^{* *}$ & 1 & $.516^{* *}$ & $.694^{* *}$ & $.487^{* *}$ & -.077 & .040 & .068 & -.055 & -.045 \\
\hline & Sig. & .000 & & .000 & .000 & .000 & .305 & .596 & .365 & .464 & .552 \\
\hline \multirow[t]{2}{*}{ Empowerment } & Corr. & $.752^{* *}$ & $.516^{* *}$ & 1 & $.764^{* *}$ & $.698^{* *}$ & -.037 & $.148^{*}$ & .054 & .037 & -.030 \\
\hline & Sig. & .000 & .000 & & .000 & .000 & .619 & .049 & .472 & .623 & .694 \\
\hline \multirow[t]{2}{*}{ Recognition } & Corr. & $.769^{* *}$ & $.694^{* *}$ & $.764^{* *}$ & 1 & $.666^{* *}$ & -.009 & .116 & .145 & -.044 & -.035 \\
\hline & Sig. & .000 & .000 & .000 & & .000 & .906 & .121 & .054 & .559 & .646 \\
\hline \multirow[t]{2}{*}{ Working Condition } & Corr. & $.704^{* *}$ & $.487^{* *}$ & $.698^{* *}$ & $.666^{* *}$ & 1 & -.056 & $.147^{*}$ & .062 & .012 & .020 \\
\hline & Sig. & .000 & .000 & .000 & .000 & & .456 & .049 & .408 & .875 & .788 \\
\hline \multirow[t]{2}{*}{ Age } & Corr. & -.035 & -.077 & -.037 & -.009 & -.056 & 1 & -.135 & -.116 & -.034 & -.031 \\
\hline & Sig. & .645 & .305 & .619 & .906 & .456 & & .073 & .121 & .649 & .684 \\
\hline \multirow[t]{2}{*}{ Education } & Corr. & $.167^{*}$ & .040 & $.148^{*}$ & .116 & $.147^{*}$ & -.135 & 1 & .059 & .011 & -.023 \\
\hline & Sig. & .026 & .596 & .049 & .121 & .049 & .073 & & .433 & .880 & .763 \\
\hline \multirow[t]{2}{*}{ Experience } & Corr. & .059 & .068 & .054 & .145 & .062 & -.116 & .059 & 1 & $-.153^{*}$ & .051 \\
\hline & Sig. & .436 & .365 & .472 & .054 & .408 & .121 & .433 & & .041 & .501 \\
\hline \multirow[t]{2}{*}{ Gender } & Corr. & .008 & -.055 & .037 & -.044 & .012 & -.034 & .011 & $-.153^{*}$ & 1 & -.060 \\
\hline & Sig. & .915 & .464 & .623 & .559 & .875 & .649 & .880 & .041 & & .425 \\
\hline \multirow[t]{2}{*}{ Salary } & Corr. & -.072 & -.045 & \begin{tabular}{|l|}
-.030 \\
\end{tabular} & -.035 & .020 & -.031 & -.023 & .051 & -.060 & 1 \\
\hline & Sig. & .341 & .552 & .694 & .646 & .788 & .684 & .763 & .501 & .425 & \\
\hline \multicolumn{12}{|c|}{$\mathrm{N}=179$} \\
\hline
\end{tabular}

As it can be seen from table 4.8; there is significant relation between the dependent variable and all independent variable under study. Employee job performance has strong positive relation with employee recognition practices accounting for $76.9 \%$ showing that the better employee recognition practices would better improve the Employee job performance. The second most correlated motivational factor with employee job performance is employee empowerment practices have also a strong positive relation which accounts $75.2 \%$ showing that improving employee empowerment practices by Fiche General Hospital will increase employee job performance and also empowering the employees at different level is shown to have direct initiation to the job performance at the same time improving the promotion and better training provision to the employees have been shown to have an ability to raise the employee's job performance level to better level. The third correlated motivational factor with employee job performance is employee working condition have strong positive relation; which accounts 70.4\% showing that better employee working condition will improve the employee job performance in Fiche General hospital. The fourth correlated motivational factor with employee job performance is employee working condition have moderate positive relation; which accounts $64.8 \%$ showing that better employee benefits package will improve the employee job performance in Fiche General hospital. Conversely, all controlling variables under study have shown to have almost insignificant/not visible relation with the employee job performance except educational qualification of participants in Fiche General Hospital. 
4.4. Regression analysis

Table 4.9: Predictors of employee job performance regression model

\begin{tabular}{|c|c|c|c|c|c|c|}
\hline \multirow{2}{*}{$\begin{array}{l}\text { Model } \\
\text { Summary }\end{array}$} & $\mathrm{R}$ & R Square & \multirow{2}{*}{$\begin{array}{r}\text { Adjusted R Square } \\
.701\end{array}$} & \multicolumn{3}{|c|}{ Std. Error of the Estimate } \\
\hline & $.846^{\mathrm{a}}$ & .716 & & \multicolumn{3}{|l|}{. .52842} \\
\hline \multicolumn{2}{|l|}{ Mode } & Sum of Squares & Df & Mean Square & $\mathrm{F}$ & Sig. \\
\hline & Regression & 118.943 & 9 & 13.216 & 47.331 & $.000^{\mathrm{b}}$ \\
\hline & Residual & 47.189 & 169 & .279 & & \\
\hline & Total & 166.131 & 178 & & & \\
\hline \multirow[b]{2}{*}{ Model } & \multicolumn{2}{|c|}{$\begin{array}{c}\text { Unstandardized } \\
\text { Coefficients }\end{array}$} & \multicolumn{2}{|c|}{$\begin{array}{l}\text { Standardized } \\
\text { Coefficients }\end{array}$} & & \\
\hline & $\mathrm{B}$ & Std. Error & \multicolumn{2}{|c|}{ Beta } & $\mathrm{t}$ & Sig. \\
\hline \multirow{10}{*}{\begin{tabular}{l}
\multicolumn{1}{c}{ (Constant) } \\
Benefits \\
Empowerment \\
Recognition \\
Condition \\
Age \\
Education \\
Experience \\
Gender \\
Salary
\end{tabular}} & .026 & .357 & & & .072 & .943 \\
\hline & .216 & .057 & \multicolumn{2}{|c|}{.220} & 3.815 & .000 \\
\hline & .281 & .069 & \multicolumn{2}{|c|}{.285} & 4.088 & .000 \\
\hline & .233 & .077 & \multicolumn{2}{|c|}{.239} & 3.021 & .003 \\
\hline & .225 & .058 & \multicolumn{2}{|c|}{.233} & 3.870 & .000 \\
\hline & .019 & .063 & \multicolumn{2}{|c|}{.012} & .296 & .768 \\
\hline & .062 & .047 & \multicolumn{2}{|c|}{.056} & 1.323 & .188 \\
\hline & -.023 & .053 & \multicolumn{2}{|c|}{-.019} & -.438 & .662 \\
\hline & .024 & .088 & \multicolumn{2}{|c|}{.011} & .274 & .785 \\
\hline & -.085 & .075 & \multicolumn{2}{|c|}{-.046} & -1.124 & .262 \\
\hline
\end{tabular}

A. Dependent Variable: Job performance

B. Predictors: (Constant), gender, experience, age, education, salary, benefits package, empowerment, recognition, working condition

The model summary table above shows the sum degree of association that the stated independent variable and controlling variables have with the dependent one that is employee job performance. As such, it has been shown by $\mathrm{R}$ that the stated independent variables (the employee motivational factors) all together with the controlling variables have stronger positive relation have at a rate of $84.6 \%$ this shows that the better the variables are treated the more the job performance of the employees will be. The R-square result in the same table being $71.6 \%$ shows that the sum total effect of the variables under consideration on the job performance of the employees in Fiche General hospital. This is to mean that certain level of improvement in the level of these motivational factors will have $71.6 \%$ positive influence on the job performance of the employees under consideration at a significant level.

The Analysis of Variance table above shows the model fitness test. The significance level (.000) proved that $\mathrm{F}$ is large enough to prove that the model used is suitable for the measurement of effects that these independent variables have on the job performance of the employees.

From the four motivational factors are employee empowerment practices $(t=4.08, P<0.05)$, employee working condition $(\mathrm{t}=3.87, \mathrm{p}<0.05)$ employee benefits package $(\mathrm{t}=3.82, \mathrm{p}<0.05)$ and employee recognition practices $(\mathrm{t}=3.02, \mathrm{P}<0.05)$ were significantly contribute for positive prediction of employee job performance.

To ascertain the level of individual contributing variable the unstandardized coefficient Beta value of the four motivational factors have been considered. The unstandardized coefficient Beta of empowerment is 0.281 , recognition is 0.233 , working condition is 0.225 and benefits package 0.216 .

Consequently, employee empowerment practices contributes more than employee recognition practices ,employee working condition and employee benefits package, since it had larger unstandardized coefficient. This finding implies that employee empowerment practices has been identified as the most determinant variable that predicted employee job performance as practiced in Fiche General Hospital.

That means as one standard deviation increase in employee empowerment the level of employee job performance increase by 0.281 ; as one standard deviation increase in employee recognition the level of employee job performance increase by 0.233 and as one standard deviation increase in employee working condition the level of employee job performance increase by 0.225 and as one standard deviation increase in employee benefits package the level of employee job performance increase by 0.216 in Fiche General hospital. Here, the contribution of employee benefits package on employee job performance is low as compared to empowerment, recognition and employee working condition in Fiche General hospital.

Depending on this fact if manager of Fiche General Hospital employed more employee empowerment, the employee job performance would be better improved.

Based on the extent of weighted beta, it can be concluded that if all independent variables are ignored, then Fiche General Hospital itself have the value of 0.026 on the employee job performance. Nevertheless, if there is one additional standard deviation changes in independent and controlling variables; empowerment, recognition, 
working condition, benefits package, education level, gender, experience, age and salary would be improved the employee job performance with a value of $28.1 \%, 23.3 \%, 22.5 \%, 21.6 \%, 6.2 \%, 2.4 \%, 1.9 \%,-2.3 \%$, and $-8.5 \%$ respectively.

The objective of the regression in this study is to find such an equation that could be used to find the effect of predictors on dependent variable. The specified regression equation takes the following form:

$\mathrm{Y}=0.026+0.281 \mathrm{X} 1+0.233 \mathrm{X} 2+0.225 \mathrm{X} 3+0.216 \mathrm{X} 4+0.062 \mathrm{X} 5+0.024 \mathrm{X} 6+0 .{ }^{`} 019 \mathrm{X} 7+(-0.023) \mathrm{X} 8+(-$ $0.085) \mathrm{X} 9+\mathrm{e}$

Where; $\mathrm{Y}$ is the job performance that used as dependent variable of the study and the explanatory variables used in regression analysis includes, $X_{1}$ is empowerment, $X_{2}$ is recognition, $X_{3}$ is working condition, $X_{4}$ is working condition, $\mathrm{X}_{5}$ is education, $\mathrm{X}_{6}$ is gender, $\mathrm{X}_{7}$ is experience, $\mathrm{X}_{8}$ is age and $\mathrm{X}_{9}$ is salary are factor that affects the employee job performance and $\mathrm{e}$ is the residual amount which are represented in the above regression model.

\section{Recommendations}

Based on the findings and conclusions of the study, the following recommendations are forwarded in order to improve the employee motivation and job performance in Fiche General Hospital. Out of study the variable, all of the study variables are under practice, particularly, employee job performance is relatively poorly practiced or the lowest score in the study area. Hence, the management of Fiche General Hospital\& other stakeholders are politely recommended to motivate employee by improving the existing benefits package; empowerment practices; recognition practices and work condition for better employee job performance.

Among the motivating factor studied the most dominant contributor for better employee job performance come from the empowerment; followed by recognition, working condition, and benefits package have the degree of first, second, third \& fourth significant effect on the employee job performance in Fiche General hospital. Hence, the concerned management body of Fiche General Hospital have been advised to give due attention for the employee empowerment practices so as to improve employee job performance. As per this study result, even though the researcher have identified the recognition, working condition, and benefit package are relatively lesser contributor to employee job performance, the management of Fiche General Hospital\& other stakeholders are also advised to give due attention for further improvement.

Notwithstanding the useful contributions of the study, it is clear that this research study had the following limitations. Firstly, the study design was a cross-sectional data or participants are only from one sector at the same time so that the findings could only be inferred to the study area. Because data were collected at one point in time, the direction of causality of the relationships examined in this study is not certain. Secondly, the scope of the study is limited to Fiche General Hospital. This means that organizations which come under a different law, other organization were not included.

Concerning the work motivational factors issue selected for the survey nearly most of the sample respondent at Fiche General Hospital where get disagree. Therefore, the management of organization understudy advisable to pay attention for improvement of employee empowerment, benefits package; work condition \& recognition in connection with their job performance practices. It advantageous, if the management of Fiche General Hospital wisely work towards developing a mechanism to motivate their needy employee on these identified gaps.

It is also valuable, if the management intervention is undertaken to visit their employee's level of their employee job performance and support them on the identified motivational factors. In order to enhance the employee motivation and their job performance at Fiche General Hospital, the management of that organization is suggested to assess their employee's needs periodically to take proper action for better organizational functioning.

\section{References}

Lawrence, S. et al. (2001). Persistence of Web References in Scientific Research. Computer. 34, 26-31. Aguinis, H. (2012). Performance Management (Second ed.). Upper Saddle River, NJ: Prentice Hall.

Baker, A.(2012). Evaluation Services, Online Sources: www: evaluationservices.com

Beer, M. \& Walton, R. E. (2014). Reward Systems and the Role of Compensation. In J. G.Searle, Manage people, not personal (p. 17). Boston: Harvard Business Review.

Bennet, S. and Franco, M.L. (1999). Public Sector Health Workers Motivation and Health Sector Reforms: A Conceptual Frame Work. Major Applied Technical Paper No.1. Bethesda, MD: Partnerships for Health Reform Project, Abt Associates Inc.

Bryman A. (2004), Social Research Methods, 2nd Edition, Oxford University Press

Inc., New York., pp.8-11

Burns, N. \& Groove, S. (2001). The Practice of Nursing Research: Conduct, Critique and Utilization, Philodophia, USA

Calista, L. (2009). Motivating employees through incentive programs, Bachelor Degree Thesis, Jyvaskyala 
University of Applied Sciences

Chandler, C. I., Chonya, S. Mtei, F., Reyburn, H. and Whitty, C.J. (2006). Motivation, money and respect: a mixed-method study of Tanzanian nonphysician clinicians, Social Science Med 2009 Jun; 68(11): pp. 207888.

Chung, K. (2013). Toward a general theory of motivation \& performance. California Management Review, Vol 11 , Issue 3,pg. 81-88.

Cole, G. A. \& Kelly, P. (2011). Management Theory and Practice. London, UK: Cengage.

Daneshkohan. D, Zarei. E., and Mansouri. T. (2015). Factors Affecting Job Motivation among Health Workers. Global Journal of Health Science, 7(3). 7 - 17.

Daniel, A. (2011). The Effect of Motivation on Staff Performance in Health Services of Ghana. A case of study of Komfo Anokye teaching hospital, Kumasi, Ghana.

Deci, , E. L. (2013). Intrinsic Motivation. New York, NY: Plennum Press.

Devadass, R. (2011). Employees Motivation in Organizations: An integrative literature review. International Conference on Sociality and Economics Development. 10, pp. 566-570. Singapore: IACSIT Press.

Dobre, O. I. (2013). Employee motivation and organizational performance. Review of Applied Socio- Economic Research, 5(1), $53-60$.

Farooq, Q., \& Shafique, M. N. (2016). Role of Intrinsic Rewards in Employee Perception and Motivation. Research on Humanities and Social Sciences, 6(5), 47-49.

Field data (2014). Data analysis from survey results (March 2014) using Questionnaires among Healthcare Facilities in Ilemela District, Mwanza Tanzania

Goble, F. 1970. The third force: The psychology of Abraham Maslow. Richmond, CA. Maurice Bassett Publishing, 62.

Hagerty, M. R. 1999. Testing Maslow's Hierarchy of Needs: National Quality-ofLife Across Time. Social Indicators Research 46(xx), 250.

Harrison, L., \& Novak, D. (2006). Evaluation of a gerontological nursing continuing education programme:Effect on nurses' knowledge and attitudes and on patients' perceptions and satisfaction. Journal of Advanced Nursing, 13 (6), 684-692.

Heale, R. \& Twycross, A. 2015. Validity and reliability in quantitative studies. Evidence-Based Nursing, 18, 6667.

Hersberg, , F. (2009). The motivation to work. New York, NY: John Wiley

Judge, T. \& Ferris, G. (2013). Social context of performance evaluation decisions. Aca demy of Management Journal, Vol 36, Issue 3, Pg. 80-10

Kothari, C. R. 1985. Research Methodology: Methods and Techniques. New Age International (P) Limited, Publishers

Kreitner, R. \& Kinicki, A. (2010). Organizational Behaviour (9th ed.). New York, NY: McGraw-Hill Irwin Inc.

Krishnaswani O.R. (2003). Methodology of Research in Social Sciences, Himalaya Publishing House, New Delhi, India

Leshabari, M.T. (2008). Motivation of Health Care Workers in Tanzania, East African Journal of Public Health. $5(1), 34-46$.

Leshabari, M.T., Muhondwa, E.P.Y., Mwangu, M. A and Mbembati, N.A.A.(2008) Motivation of Health Care Workers in Tanzania: A case study of Muhimbili National Hospital, East African Journal of public Health, $5(1): 32-37$

Malekia, S. E. (2009). Factors associated with motivation among HealthCare Workers in Plublic Primary Healthcare Facilities in Dar-es-Salaam, Masters' Degree Thesis. Muhimbili University of Health and Allied Sciences, Tanzania

Manongi , R.N, Marchant, T.C. and Bygbjerg, I. C. (2006). Improving motivation among Primary Healthcare Workers in Tanzania: a Health Worker Perspective, Human Resources for Health, pp. 1-6

Manongi, et,al (2006). Improving motivation among Primary Healthcare Workers in Tanzania: a Health Worker Perspective, Human Resources for Health, pp. 1-6

Manzoor, Q.-A. (2012). Impact of Employee Motivation and Organizational Effectiveness. European Journal of Business and Management, 3(3), 36-44.

Maslow, A.H. (1943). A Theory of Human Motivation. Psychological Review, Harper and Row Publisher, New York, USA

Masydzulhak, Ali, H., \& Anggraeni, L. D. (2016). The Influence of work Motivationand Job Satisfaction on Employee Performance and Organizational Commitment Satisfaction as an Intervening Variable in PT. Asian Isuzu Casting Center. Journal of Research in Business and Management, 4(10), 01-10.

Matsie, M. (2008). The impact of motivation on employee performance at level one district hospitals, with special reference to Metsimaholo district hospital in sasolburg. North-West University (Vanderbijlpark Campus), Management. Vanderbijlpark: unpublished. 
McEwen, M. \& Wills, E. M. 2014. Theoretical Basis for Nursing. Philadelphia. Wolters Kluwer Health/Lippincott Williams \& Wilkins .

Memmott, L. and Growers, S. (2012). Retaining and Motivating Employees. Washington DC: WSU Publishers.

Mitchell, T. R., \& Liden, R. C. (2012). The effects of the social context on performance

evaluations.

Mosley, D. C., Pietri, P. H. \& Mosley Jnr, D. C. (2012). Supervisory Management: The Artof Inspiring, Empowering and Developing People. Mason, OH: Thompson South-Western Muhondwa, E.P. and Leshabari, M.T. (2008) Performance indicators for quality in surgical and laboratory services at Muhimbili national hospital (MNH) in Tanzania. East African Journal of Public Health5 (1): pp13-16.

Muogbo, U. S. (2013). The Influence of Motivation on Employees' Performance: A Study of Selected Firms in Anambra State. AFRREV an International Journal of Arts and Humanities, 2 (3), 134-151.

Muralidharan, K., \& Sundararaman, V. (2009). Teacher performance pay: Experimental evidence from India. National Bureau of Economic Research, 1(1), 1-48.

Muze, R. W. (2014). Assessment of Motivation and Its Impact on Employees' Performance in Goal Attainment: A Case of Vodacom Tanzania Limited. Unpublished thesis submitted to Open University of Tanzania.

O'Gorman, K. D. \& MacIntosh, R. 2014. Research Methods for Business Management. Oxford. Goodfellow.

Ojukuku, R. M., and Salami, A. O. (2011). Contextual influences of health workers motivations on performance in university of Ilorin teaching hospital. American Journal of Scientific and Industrial Research, 10(3), 126 $-142$.

Riggio, R. E. (2014). Introduction to Industrial/ Organizational Psychology. Upper Saddle River, NJ: Prentice Hall.

Sandhya, K., \& Kumar, D. (2011). Employee Retention by Motivation. Madanapalle : Madanapalle Institute of Science and Technology.

Shaheen, A., Naqvi, S. M., \& Khan, M. A. (2013). Employees Training and Organizational Performance: Mediation by Employees Performance. Interdisciplinary Journal of Contemporary Research Business, 5(4), 490-503.

Silberstein, 2017. The hierarchy of Needs for Employees. Accessed 3.9.2017. http://smallbusiness.chron.com/hierarchy-needs-employees- 20121.html.

Skemp-Arlt, K.M., Toupence, R. 2007. The administrator's role in employee motivation. Coach \& Athletic Director, 28-34.

Stanley, T. L. (2012). Motivation in today's workplace. Human Resource Journal, Vol.55, Issue 7, pg. 1-9.

Steers, R. M. \& Porter, L. W. (2011). Motivation and work performance. New York, NY:McGraw-Hill.

Temesgen, A. (2012). Analysis of instructors' empowerment evidence from Mekelle University. Mekelle University, Management. Mekelle: unpublished.

Tizazu, K. (2015, March 3). Employee Motivation and its Effect on Employee Retention in Ambo Mineral Water Factory. 7International Journal of Advance Research in Computer Science and Management Studies, 19.

UNDP. (2014). Motivation of Public Service Officials Insights for Practitioners. Singapore: UNDP Global Centre for Public Service Excellence. 6 